\title{
The Influence of Undergrowth Distribution on Utilization of Space by Bank Vole Populations
}

\author{
Maria MAZURKIEWICZ
}

\begin{abstract}
Mazurkiewicz M., 1986: The influence of undergrowth distribution on utilization of space by bank vole populations. Acta theriol., 31, 4: 55-69. [With 2 Tables \& 7 Figs.]

Studies were made in 1-hectare areas situated in 9 types of tree stand of the influence of clustered and random distribution of undergrowth on the spatial organization of Clethrionomys glareolus (Schreber, 1780). It was found that in areas with clustered undergrowth the population made use of a smaller space and reached greater local densities (on the utilized site) when total density was the same, as compared with areas in which undergrowth was distributed at random. In all ranges of local densities the home ranges were larger where there was random undergrowth distribution than where it was clustered, while the mean number of animals on a trapping site, forming the measure of contacts between individuals, was maintained on a similar level. In both types of area (clustered or random undergrowth distribution) the home ranges of sexually active females were similar in size, and the mean number of females on a trapping site was approximately 1 , regardless of their local density.

[Inst. Ecol., Polish Acad. Sci., Dziekanów Leśny, 05-092 Łomianki, Poland]
\end{abstract}

\section{INTRODUCTION}

Among the large number of factors affecting occurrence and numbers of small rodents the amount of shelter afforded by a habitat is of great importance. Hansson (1978) stated quite simply that the group of external factors influencing the occurrence of small rodents may be defined by a single term - shelter. The influence of the amount of shelter in a habitat, both from predators and other individuals of the same species, on dynamics of numbers has beeen emphasized by many authors. In a forest habitat different elements of its structure, such as undergrowth cover of the area (Gubar, 1974; Miller \& Getz, 1972, 1973; van Horne, 1982; Jensen, 1982; Wiger, 1981); “debris" (Miller \& Getz, 1972, 1973, Geuse, 1982); formation of the ground, e.g. fissures (Smal \& Fairley, 1981) or density of tall ferns (Geuse, 1982), may play this role. Mazurkiewicz (1984), in analyzing the same material as that forming the subject of the present paper, found that the basic factor responsible for a $C$. glareolus population attaining different maximum numbers in different tree stands is the density of the undergrowth. At the same time she drew attention to the fact that the size of the area used by 
voles when population numbers are similar depends on the character of undergrowth distribution in the area. It would seem that the varying proportion of space in the habitat suitable for utilization by the population may exert an important influence on its spatial organization.

The purpose of the present study was to determine the form taken by such elements of spatial organization of a $C$. glareolus population as size of space utilized, size of home ranges and degree to which they overlap, when there are different numbers of these animals in tree stands with either clustered or random distribution of undergrowth.

\section{STUDY AREA, METHODS AND MATERIAL}

The studies wehe carried out from 1976 to 1981 in the Puszcza Piska forest complex (north-east Poland) in 9 different tree stands, as follows: oak-hornbeam forests (Tilio-Carpinetum) 260 and 120 years old; mixed coniferous forest (PinoQuercetum) 144 years old; moist coniferous forest (Sphagno girgensohnii-Piceetum) 120 years old; pine monocultures $10,15,90$ and 140 years old and pine-spruce forest 110 years old. The pine monocultures and the pine-spruce forest were situated in a mixed coniferous forest habitat, while the remainder were natural tree stands.

Data on numbers and distribution of bank voles were collected by the CMR (Catch-Mark-Release) method. 1-hectare areas were set up in each of the selected tree stands and a grid of live traps arranged in each at $15 \times 15 \mathrm{~m}$ intervals. Every year 4 trapping series at approximately 6-weekly intervals were carried out from spring (end of May) to autumn (mid-October), each trapping series lasting 7 days, during which the traps were inspected twice daily. During inspection of the traps the animals caught were marked by toe-clipping, recording the sex, place of capture and sexual activity (females - open or closed vagina, males - testes in the scrotum or not).

The material collected represented 11205 captures of 3149 individuals (Table 1).

Table 1

Number of individuals analyzed in different areas in successive years.

\begin{tabular}{|c|c|c|c|c|c|c|c|c|}
\hline \multicolumn{3}{|c|}{ Study area } & \multicolumn{5}{|c|}{ Number of individuals } & \multirow[b]{2}{*}{1981} \\
\hline No. & $\begin{array}{l}\text { Type of } \\
\text { tree stand }\end{array}$ & $\begin{array}{l}\text { Age of tree } \\
\text { stand, yrs. }\end{array}$ & 1976 & 1977 & 1978 & 1979 & 1980 & \\
\hline 1 & Deciduous forest & 260 & 46 & 52 & & & & \\
\hline 2 & Deciduous forest & 120 & 44 & 107 & & & & \\
\hline 3 & Moist coniferous forest & 120 & 28 & 61 & & & & \\
\hline 4 & Pine-spruce forest & 110 & & & 26 & 28 & 20 & \\
\hline 5 & Pine monoculture & 10 & & 16 & 62 & 45 & 112 & 218 \\
\hline 6 & Pine monoculture & 140 & & 152 & 122 & 121 & 115 & \\
\hline 7 & Pine monoculture & 90 & & 114 & 54 & 93 & & \\
\hline 8 & Pine monoculture & 15 & & 82 & 215 & & & \\
\hline 9 & Mixed forest & 144 & & & 107 & 92 & 102 & \\
\hline
\end{tabular}


Description of the habitats included estimates of the age of the given tree stand, type of habitat and density and species composition of trees and bushes, taking into consideration their occurrence in different layers. For this purpose from 40-75 squares (depending on the spatial heterogeneity of the tree stand) $100 \mathrm{~m}^{2}$ in extent were marked out in each area, and all trees and bushes there were counted.

\section{RESULTS}

\subsection{Description of the Species and Spatial Structure of the Undergrowth}

Different areas were characterized by different degrees of species: diversity in the undergrowth layer, from 11 species in the 10-year old pine monoculture to 1 species in the moist coniferous forest. The dom-

Table 2

Species structure (number of species, dominating species, their percentage), percentage of area covered by undergrowth, density and value of index $I_{8}$ of undergrowth clustering in different study areas (order of areas as in Table 1).

\begin{tabular}{|c|c|c|c|c|c|c|}
\hline \multirow[b]{2}{*}{$\begin{array}{l}\text { No. of } \\
\text { area }\end{array}$} & \multicolumn{6}{|c|}{ Description of undergrowth } \\
\hline & $\begin{array}{l}\text { species } \\
\text { No. of }\end{array}$ & $\begin{array}{c}\text { species } \\
\text { Dominating }\end{array}$ & $\%$ & $\begin{array}{l}\% \text { of } \\
\text { covered } \\
\text { area }\end{array}$ & $\begin{array}{l}\text { per } 100^{2} \\
\text { Density }\end{array}$ & Is \\
\hline 1 & 10 & $\begin{array}{l}\text { Ash } \\
\text { Hornbeam } \\
\text { Hazel } \\
\text { Others }\end{array}$ & $\begin{array}{r}49.5 \\
31.0 \\
5.9 \\
3.4\end{array}$ & 26 & 5.67 & $4.57^{1}$ \\
\hline 2 & 10 & $\begin{array}{l}\text { Ash } \\
\text { Hornbeam } \\
\text { Hazel } \\
\text { Others }\end{array}$ & $\begin{array}{r}31.0 \\
48.0 \\
19.0 \\
2.0\end{array}$ & 82 & 17.60 & $1.35^{1}$ \\
\hline 3 & 1 & Spruce & 100.0 & 79 & 3.40 & $1.79^{1}$ \\
\hline 4 & 2 & $\begin{array}{l}\text { Hazel } \\
\text { Spruce }\end{array}$ & $\begin{array}{c}70.6 \\
29.4\end{array}$ & 10 & 0.50 & $5.43^{1}$ \\
\hline 5 & 11 & $\begin{array}{l}\text { Birch } \\
\text { Pine } \\
\text { Hornbeam } \\
\text { Others }\end{array}$ & $\begin{array}{r}36.0 \\
23.0 \\
9.0 \\
32.0\end{array}$ & 85 & 35.20 & $1.56^{t}$ \\
\hline 6 & 7 & $\begin{array}{l}\text { Hazel } \\
\text { Hornbeam } \\
\text { Spruce } \\
\text { Others }\end{array}$ & $\begin{array}{r}90.0 \\
3.6 \\
2.4 \\
4.0\end{array}$ & 100 & 18.80 & 1.01 \\
\hline 7 & 4 & $\begin{array}{l}\text { Hazel } \\
\text { Spruce } \\
\text { Others }\end{array}$ & $\begin{array}{r}92.0 \\
7.0 \\
1.0\end{array}$ & 100 & $\begin{array}{l}9.13 \\
.\end{array}$ & 0.99 \\
\hline 8 & 4 & $\begin{array}{l}\text { Hazel } \\
\text { Hornbeam } \\
\text { Spruce } \\
\text { Others }\end{array}$ & $\begin{array}{r}80.0 \\
10.5 \\
7.8 \\
1.7\end{array}$ & 94 & 8.32 & 1.06 \\
\hline 9 & 7 & $\begin{array}{l}\text { Pine } \\
\text { Hazel } \\
\text { Spruce } \\
\text { Others }\end{array}$ & $\begin{array}{r}57.0 \\
22.0 \\
8.5 \\
12.5\end{array}$ & 98 & 28.7 & 1.00 \\
\hline
\end{tabular}

${ }^{1}$ I $8>1$ when $p<0.5$. 
inating species in the undergrowth on most of the study areas were: hazel, hornbeam, ash and spruce. The various areas different in respect of mean undergrowth density from 0.5 individuals per $100 \mathrm{~m}^{2}$ in the pine-spruce forest to 35.2 specimens in the 10 -year old pine monculture, and also in respect of the extent of the area covered by undergrowth (Table 2).

The type of spatial distribution of undergrowth in the different study areas was examined by means of Morisita's index (1959):

$$
I \delta=q \frac{\sum n_{i}\left(n_{i}-1\right)}{N(N-1)}
$$

where: $q$ - number of sample areas $(10 \times 10 \mathrm{~m}), n_{t}$ - number of individuals of undergrowth on $i$ area, $N-$ total number of individuals on $q$ areas.

$I \delta=1$ indicates random distribution; $I \delta<1-$ even distribution; $I \delta>1$ - clustered distribution. The significance of deviation of the values obtained for $I \delta$ from 1 (divergence from Poisson's distribution) was checked by using the following test:

$$
F_{0}=\frac{I_{8}(N-1)+q-N}{q-1}
$$

If $F_{\circ}$ is greater than $F_{\infty}{ }^{\alpha-1}(\alpha)$ then distribution is significantly different from random.

It was found that the undergrowth in the study areas situated in oak-hornbeam forests, the moist coniferous forest, pine-spruce forest and 10-year old pine monoculture was characterized by clustered distribution, while in the remaining areas (pine monocultures 15, 90, 140 year old and mixed coniferous forest, distribution is random (Table 2).

\subsection{Size of Space Utilized by Populations Similar in Numbers Depending on the Character of Undergrowth Distribution}

Mazurkiewicz (1984) found that the greater the density of the undergrowth, the greater the maximum numbers attained by a population of bank voles, and that with similar numbers the population utilizes a greater space where the distribution of undergrowth density in the study area varies to a lesser degree.

A check was made to ascertain if there is any relation between the size of the area utilized by the bank vole (percentage of trapping sites on which at least one individual was caught during a trapping series) 
and the type of spatial distribution of the undergrowth. The trapping series on the various areas, during which the numbers of the populations were similar, were chosen for analysis.

A negative relation was found between the size of the area utilized by the bank vole and the value of the index of the clustered character of the undergrowth $(r=-0.969 ; p<0.001)$. This relation takes the form of the exponent function $y=57.96 x^{-0.6307}$. With random distribution of the undergrowth in an area the population utilizes over $50 \%$ of the area, whereas with clustered distribution there is an abrupt decrease in the size of the area utilized by the bank vole (Fig. 1).

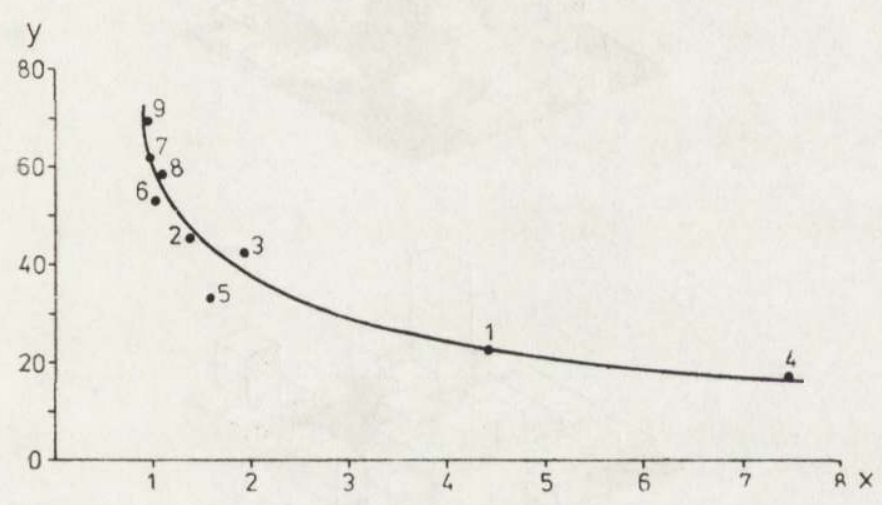

Fig. 1. Relation between percentage of trapping sites visited per area utilized (y) and index of clustered distribution $I_{3}(x)$ with similar population numbers in different areas. Numbers of areas as in Table 1.

An example of differing size of area utilized by two populations, one of which occupied an area with clustered undergrowth distribution (oak-hornbeam forest 260 years old), the other with random undergrowth distribution (pine monoculture 140 years old) at a time of similar population numbers ( 32 and 35 individuals) is given in Fig. 2. In the pine monoculture the voles utilized significantly more trapping sites than in the oak-hornbeam forest $(0.001<p<0.01)$.

All the study areas were divided into two groups depending on the relation found between extent of space utilized by the bank vole population and character of undergrowth distribution. The first group included areas with random distribution of undergrowth (termed type $R$ areas), situated in the 15,90 and 140 years old pine moncultures, and in the mixed coniferous forest. The second group consisted of areas with clustered undergrowth distribution (type $\mathrm{C}$ areas); situated 
in oak-hornbeam forests, moist coniferous forest, pine-spruce forest and 10-year old pine monoculture (Table 2, Fig. 1). All further comparisons have been made for these two ( $R$ and $C$ ) types of area. The data analyzed came from 36 samples (trapping series taken for analysis) for each type of area.
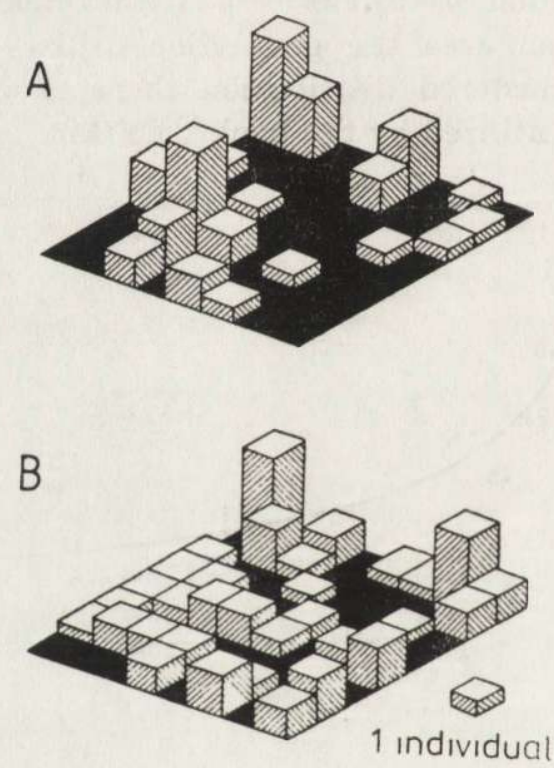

Fig. 2. Distribution of number of individuals caught on different trapping sites during one trapping series. A -260 year old oak-hornbeam forest (clustered distribution of undergrowth), B - pine monoculture, 140 years old (random distribution of undergrowth).

3.3. Influence of Increase in Population Numbers on the Size of Space Utilized

Examination was made of the way in which space is utilized by the bank vole during a period of increase in population numbers (from May to September) in type $\mathrm{R}$ and $\mathrm{C}$ areas.

For this purpose investigation was made of the relation between population numbers estimated by the MNP method (Minimal Numbers Present) and the percentage of trapping sites visited by bank voles in type $\mathrm{R}$ and $\mathrm{C}$ areas. Analysis was made for values of size of utilized area in number intervals of every 10 individuals.

A positive relation was found between population numbers and size of utilized space for both types of area. This relation takes on the form of a logarithmic function and is highly significant (for area type $\mathrm{R}$ : $r=0.922, p<0.001$; for area type C: $r=0.889, p<0.001$ ). In type $\mathrm{R}$ areas, 
however, occupation by the bank voles of free space (new trapping sites) takes place more rapidly as numbers increase and remains on a higher level than in type $\mathrm{C}$ areas $(p=0.001)$. Populations occupying type $\mathrm{R}$ areas utilize more space with the same population numbers than is the case with populations occupying type $\mathrm{C}$ areas (Fig. 3).

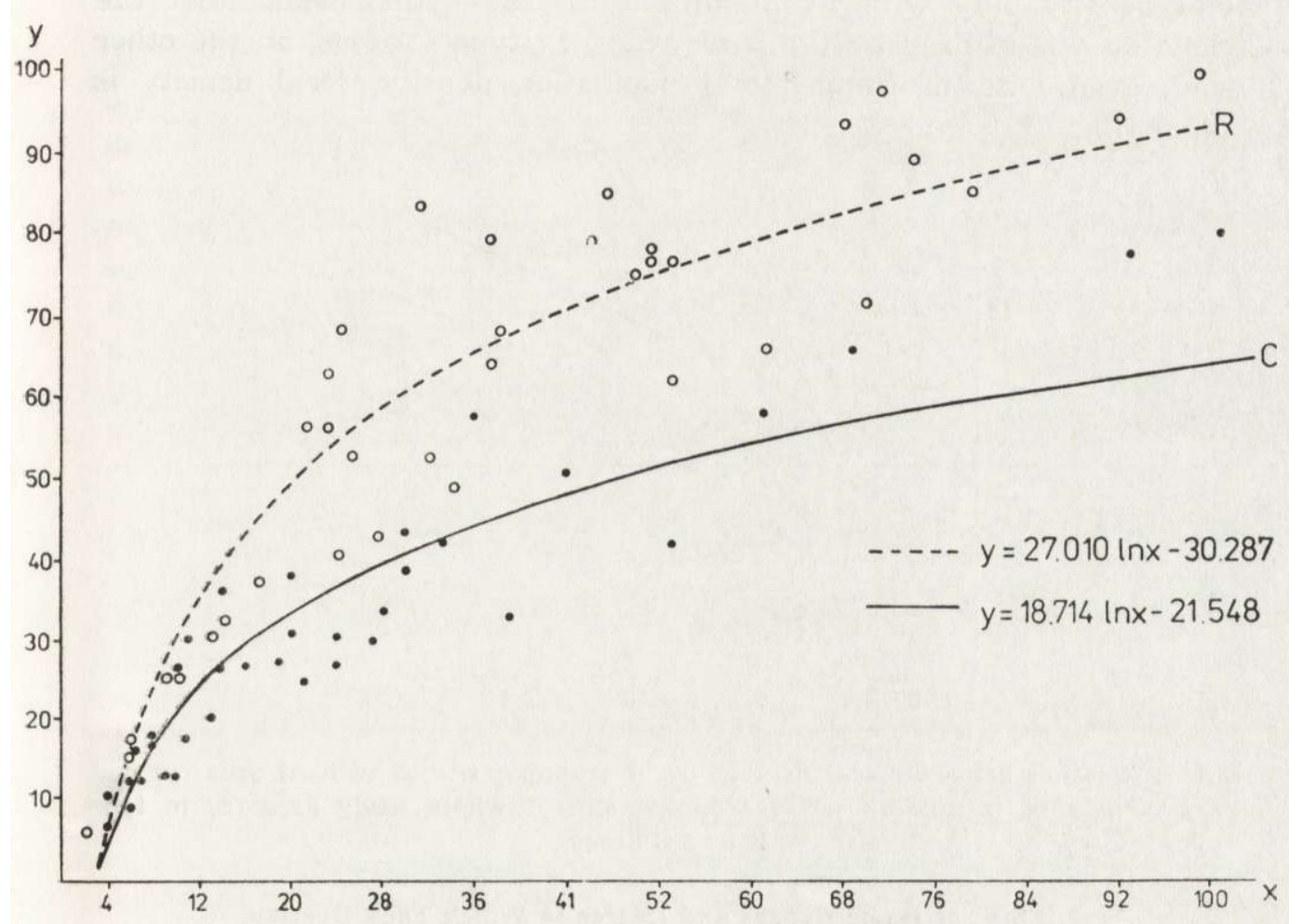

Fig. 3. Relation between size of utilized area $(y)$ and population numbers $(x)$ in areas with random (type $R$ ) and clustered (type C) distribution of undergrowth.

The above finding suggests that depending on the size of the space utilized, a population may reach different local densities (mean number of individuals recorded in a given trapping series per 1 trapping site of a utilized area), despite similar local density (mean number of individuals recorded in a given trapping series per 1 trapping site of the whole study area). When the whole area is utilized (all trapping sites) local density will be equal to total density.

Examination was made of the way in which local density of individuals depending on total population density occurs in the two types of area 
it was found that in both types of area local density increases together with increase in total density (for type $\mathrm{R}$ area: $r=0.957, p<0.001$; for type $\mathrm{C}$ area: $r=0.859, p<0.001$ ). In all ranges of total densities in type $\mathrm{C}$ areas local density is maintained on a higher level than in type $\mathrm{R}$ areas $(0.002<p<0.001)$. In type $R$ areas local density comes close to total density only with its maximum values - this means that the whole area is utilized by the bank voles. In type $\mathrm{C}$ areas, on the other hand, even with maximum total population density, local density is higher (Fig. 4).

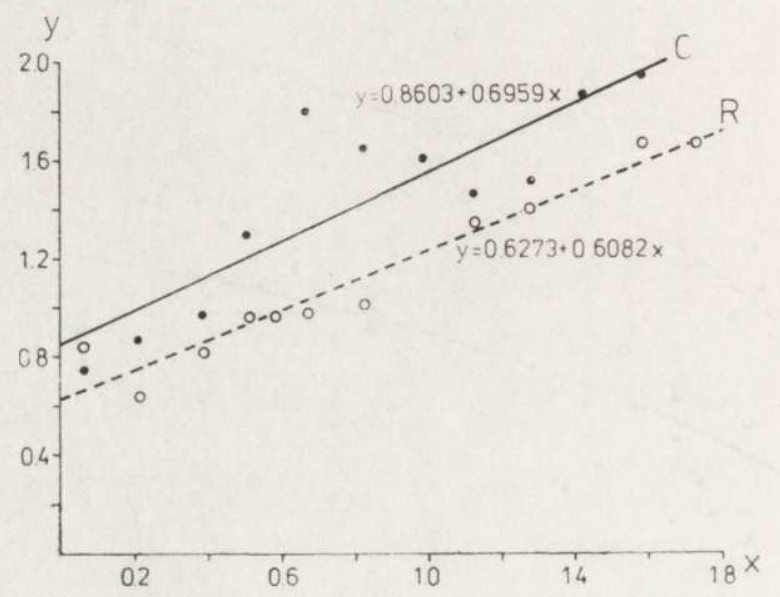

Fig. 4. Relation between local density per 1 trapping site of utilized area $(y)$ and total density of population per 1 trapping site of whole study area $(x)$ in type $\mathrm{R}$ and $\mathrm{C}$ areas.

\subsection{Size of Home Ranges and Degree to Which They Overlap}

Investigation was made of the size of home ranges and the degree to which they overlap depending on local density of bank voles during a period of increase in population numbers (end of May - beginning of September).

The size of the home range was determined by means of two indices: maximum distance between trapping sites visited by a given animal and the number of trapping sites visited by an individual during a given trapping series. The analysis included individuals which were caught at least twice during a trapping series, after first establishing the absence of significant differences between the mean number of captures per individual in type $\mathrm{R}$ and $\mathrm{C}$ areas. Calculation was made from the values of home range size, obtained for various individuals, of the mean values for the whole population and also separately for sexually active 
females for each trapping series. By distinguishing this group of individuals characterized by higher numbers in type $\mathrm{R}$ than in type $\mathrm{C}$ areas: (Mazurkiewicz, unpublished) it was intended to check if the difference of space suitable for occupation and reproduction in these areas also affects the spatial organization of sexually active females.

The relation between mean size of home ranges and local density of the population was examined. A significant negative relation was found between the mean size of home ranges expressed by the mean maximum distance between trapping sites of an individual and local population density in both types of area (relation for type $\mathrm{R}$ area: $r=-0.856$, $p<0.001$; for type C area: $r=-0.958, p<0.001$ ). With low local population densities even a slight increase in density causes a considerable decrease in the size of home ranges, while with greater densities reduction in the size of home ranges is far slower. The difference occurring in home range size between type $\mathrm{R}$ and $\mathrm{C}$ areas is on the border line: of significance $(0.1>p>0.05$; Fig. 5).

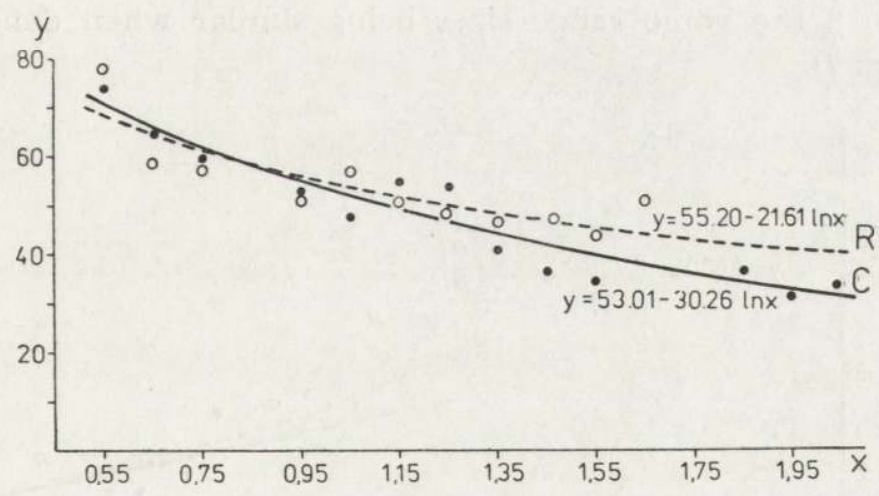

Fig. 5. Relation between mean distance between extreme trapping sites of an individual expressed in meters $(y)$ and local density of population $(x)$ in type $\mathrm{R}$ and $\mathrm{C}$ areas.

A significant negative relation was also found between local population density and the second calculated index of home range size mean number of trapping sites visited by an individual (for type $\mathrm{R}$ areas: $r=-0.852, p<0.001$; for type $\mathrm{C}$ areas: $r=-0.681,0.001<p<0.005$ ). It was also found that within the whole range of local densities the mean home range size is greater in type $\mathrm{R}$ than in type $\mathrm{C}$ areas $(0.002<p<0.001$; Fig. 6$)$.

Analysis was made of home range size of sexually active females depending on their local density in type $\mathrm{R}$ and $\mathrm{C}$ areas.

As in the case of analysis of home range size for the whole popu- 


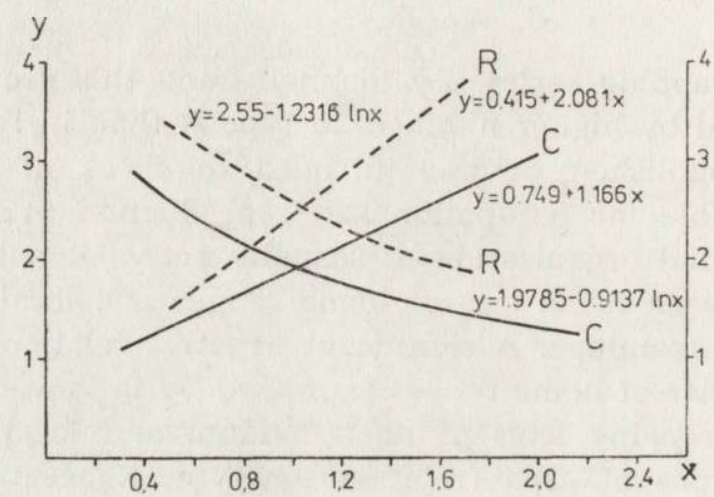

Fig. 6. Relation between mean number of trapping sites visited and mean number of individuals per site $(y)$ and local density $(x)$ in type $\mathrm{R}$ and $\mathrm{C}$ areas.

lation, a negative relation was found in both types of area between home range size of sexually active females and their local density (for type $\mathrm{R}$ areas $r=-0.802, p<0.001$; for type $\mathrm{C}$ areas $r=-0.691$, $0.001<p<0.01$ ), the home range sizes being similar when densities are identical (Fig. 7).

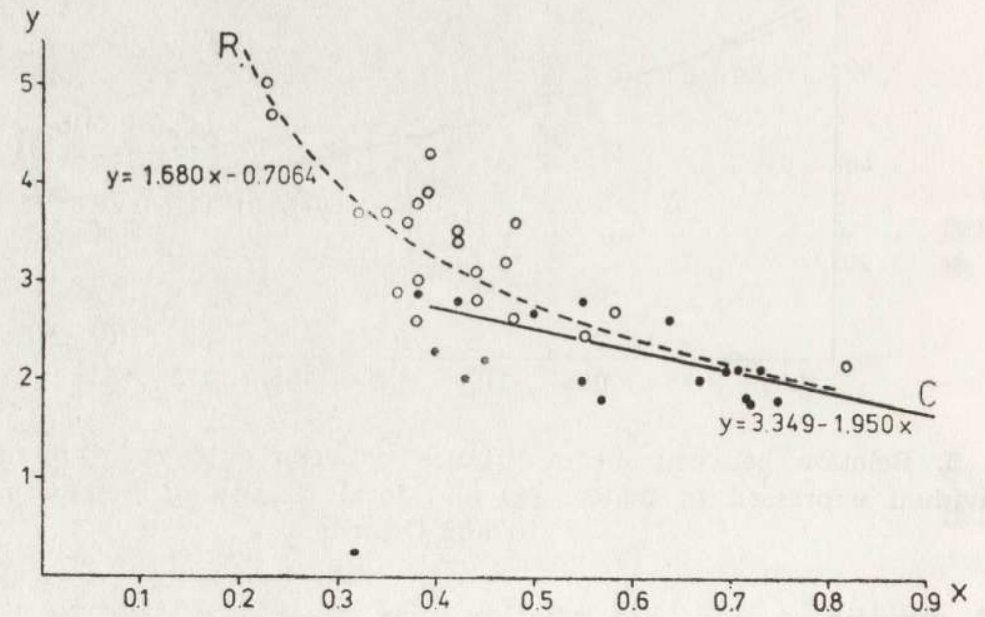

Fig. 7. Relation between mean number of trapping sites visited by sexually active females $(y)$ and their local density $(x)$ in type $\mathrm{R}$ and $\mathrm{C}$ areas.

The degree of overlapping of home ranges in different areas was estimated by calculating for each trapping series the mean number of individuals caught on one trapping site. Examination was made of the relation between local population density and degree of overlapping of home ranges. A positive straight line relation was found between local 
density and degree of overlapping of home ranges (for type $\mathrm{R}$ areas: $r=0.720, p<0.001$; for type $\mathrm{C}$ areas: $r=0.752, p<0.001$ ). The rate of increase in overlapping of home ranges with increase in local density is significantly greater in type $\mathrm{R}$ areas than in type $\mathrm{C}$ areas $(0.01<p<$ 0.02 ) (Fig. 6). No such relation was found for sexually active females, and the degree of overlapping of their home ranges varied round 1 in the whole range of their local densities.

\section{DISCUSSION}

The basic element of habitat structure affecting numbers and distribution of Clethrionomys populations is a well-developed undergrowth layer (Brown, 1956; Wiger, 1981; Mazurkiewicz, 1984). The importance of this habitat element has also been found for populations of other species of rodents such as Clethrionomys gapperi (Miller \& Getz, 1972, 1973), Clethrionomys rutilus (Gubar, 1974), Microtus longicaudus (van Horne, 1981), Peromyscus leucopus (Dusser \& Shugart, 1978).

Rozenzweig and Winakur (1969) found that the clustered distribution of forest rodents is influenced more by spatial structure than species composition of vegetation, and the results presented provide confirmation of this opinion. Spatial distribution of the undergrowth influences not only the attainment by a bank vole population of lesser or greater maximum numbers (Mazurkiewicz, 1984), but also its spatial organization. In spring a sparse population occupies only that part of the habitat providing most favourable conditions for them. As numbers rise as the result of reproduction, occupation of free space suitable for them to live in takes place. In areas (type C) where the undergrowth is distributed in patches forming clusters, slower and never complete occupation of free space is observed in relation to the areas (type $R$ ) where the undergrowth is more evenly distributed. It would seem that the individuals in a population do not readily occupy open space (devoid of undergrowth), probably on account of the danger of attack from predators.

Grant and Morris (1971) put forward the hypothesis that the relation between the distribution of animals and of the structural elements of a habitat disappears as population density increases. The data obtained show that populations exhibit rather a tendency to organize themselves in space primarily in areas optimal for their occupation (with bush cover). The greater local density maintained in type $\mathrm{C}$ areas then in type $\mathrm{R}$ areas is evidence of this, since in the latter, with maximum population numbers, the whole of the study space proved to be utilized.

The different character of utilization of space depending on the spatial distribution of the undergrowth has its consequences for the pop- 
ulation's spatial organization. In the present paper it has been described by indices of home range size and the degree to which home ranges overlap. In type $\mathrm{C}$ areas voles have smaller home ranges than in type $R$ areas, and this difference is maintained within the whole range of local densities. The rate of reduction in size of home ranges together with increase in density is similar in both types of area. The negative relation between population density and home range size has been found by a large number of authors (Gaines \& Johnson 1982; Getz, 1961; Krebs, 1966; Viitala, 1977; Abramsky \& Tracy, 1980; Andrzejewski \& Mazurkiewicz, 1976; Mazurkiewicz, 1981). Pearson (1953) and Brown (1969) explained this phenomenon in the following way: the individuals in a population adapt the size of their home ranges to the number of neighbours in order to limit contacts between individuals. The smaller home ranges, and also their lesser overlapping found in type $\mathrm{C}$ than in type $\mathrm{R}$ areas, would appear to support this opinion. In type $\mathrm{C}$ areas with higher local density the voles penetrate smaller areas and in this way avoid excessive contacts with each other. In type $\mathrm{R}$ areas, on the other hand, with lesser local density the individuals penetrate more extensive spaces, but probably do not increase the number of contacts with other animals. Cooper (1978) and Metzgar (1971) suggest that with different densities a different degree of tolerance occurs among individuals in a population as to the degree to which their home ranges overlap. This is also confirmed by the data obtained on home range size and degree of overlapping in the case of sexually active females, which exhibit territorial tendencies (Bujalska, 1970; Naumov, 1951; Aristova, 1970). It was found that it is only with low local densities that sexually active females have larger home ranges in type $\mathrm{R}$ areas. Increase in density causes a similar decrease in home range size in this group of animals in both types of area. It was simultaneously shown that the degree of overlapping of home ranges in the case of sexually active females is maintained on a constant level regardless of their local density.

The results presented here indicate, although in a very general way, that a bank vole population adapts its spatial organization to different distribution of undergrowth in a forest habitat, as is shown by the higher local densities of population and smaller home ranges in areas with clustered distribution of undergrowth than in those where undergrowth distribution is random. This permits of maintaining a similar, probably optimal number of contacts between individuals in a smaller space than that in areas with greater utilizable space. The fact that this factor exerts a weaker influence on the spatial organization of sexually active females than on spatial organization of the whole pop- 
ulation is also remarkable. It is likely that these females, with their considerable space and food requirements connected with reproduction, appear rather to adapt their numbers to different habitat conditions.

\section{REFERENCES}

1. Abramsky Z. \& Tracy C. R., 1980: Relation between home range size and regulation of population size in Microtus ochrogaster. Oikos, 34: 347-355.

2. Andrzejewski R. \& Mazurkiewicz M., 1976: Abundance of food supply and size of bank voles home range. Acta theriol., 21: 237-253.

3. Aristova V. A., 1970: Osobennosti ispol'zovanija territorii krasnoj polevki v lesach južnoj časti Kirovskoj oblasti. Fauna i ekologija gryzunov, 9: 151-159.

4. Brown L. E., 1956: Movements of some British small mammals. J. Anim. Ecol., 25: $54-71$.

5. Brown L. E., 1969: Field experiments on the movements of Apodemus sylvaticus L. using trapping and tracking technique. Oecologia, 2: 198-222.

6. Bujalska G., 1970: Reproduction estabilizing elements in an island population of Clethrionomys glareolus. Acta theriol., 15: $381-421$.

7. Cooper W. E. Jr., 1978: Home range size and population dynamics. J. Theor. Biol., 75: 232-337.

6. Bujalska G., 1970: Reproduction stabilizing elements in an island population mammal fauna. Ecology, 59: 89-98.

9. Gaines M. S. \& Johnson M. L., 1982: Home range size and population dynamics in the prairie vole, Microtus ochrogaster. Oikos, 39: 63-70.

10. Getz L. L., 1961: Factors influencing the local distribution of Microtus and Synaptomys in southern Michigan. Ecology, 48: 694-697.

11. Geuse P., 1982: Spatial microhabitat of Bank vole and Wood mice in a forest of central Belgium. Third Intern. Theriol. Congress., Abstracts of papers: 116. Helsinki.

12. Gubar J. P., 1974: Stacij Krasnoj polevki (Clethrionomys rutilus Pall.) Onežskogo pouostrova. Fauna i Ekol. Zhiv., Nauka, Moskva: 174-188.

13. Grant P. R. \& Morris R. D., 1971: The distribution of Microtus pennsylvanicus within grassland habitat. Can. J. Zool., 49: 1043-1051.

14. Hansson L., 1978: Small mammal abundance in relation to environmental variables in three Swedish forest phases. Stud. Forest. Suec., 147: 5-39.

15. Jensen T. S., 1982: Habitat distribution, home range and movements of rodents in mature forest and reforestations. Acta Zool. Fennica, 171: 305-307.

16. Krebs C. J., 1966: Demographic changes in fluctuating populations of Microtus californicus. Ecol. Monogr., 36: 239-273.

17. Mazurkiewicz M., 1981: Spatial organization of bank vole populations in years of small or large numbers. Acta theriol., 26: 31-45.

18. Mazurkiewicz M., 1984: Population density of small rodents as affected by chosen elements of tree stand structure. Bull. Acad. Pol. Sci. Cl. II., 32: 209-217 .

19. Metzgar L. H., 1971: The measurement of dispersion in small mammal populations. J. Mammal., 52: 12-20.

20. Miller D. H. \& Getz L. L., 1972: Factors influencing the local distribution of the redbacked vole Clethrionomys gapperi in New England. Univ. Connecticut. Occas. Papers, Biol. Sci., Ser., 2: 115-138. 
21. Miller D. H. \& Getz L. L., 1973: Factors influencing the local distribution of the redbacked vole Clethrionomys gapperi in New England. II. Vegetation cover, soil moisture and debris cover. Univ. Connecticut Occas. Papers, Biol. Sci., Ser., 2: 159-180.

22. Morisita M., 1959: Measuring of the dispersion of individuals and analysis of the distributional patterns. Mem. Fac. Sci. Kyushu Univ., E, Biol., 2: 4.

23. Naumov N. P., 1951: Novyj metod izučenija ekologii melkich lesnych gryzunov Fauna i ekologija gryzunov, 4: 3-21.

24. Pearson P. G., 1953: A field study of Peromyscus population in Gulf Hammock, Florida. Ecology, 34: 199-207.

25. Rozenzweig M. L. \& Winakur J., 1969: Population ecology of desert rodent communities: habitats and environmental complexity. Ecology, 50: 558-572.

26. Smal C. M. \& Fairley J. S., 1981: The dynamics and regulation of small rodent populations in the woodland ecosystems of Killarney, Ireland. J. Zool. Lond., 196: $1-30$.

27. Van Horne B., 1981: Demography of Peromyscus maniculatus populations in several stages of coastal coniferous forest in southeast Alaska. Can. J. Zool., 59: $1045-1961$.

28. Van Horne B., 1982: Demography of the longtail vole Microtus longicaudus in several stage of coastal coniferous forest in southeast Alaska. Can. J. Zool., 60: $1690-1709$.

29. Viitala J., 1977: Social organization in cyclic subarctic populations of the voles Clethrionomys rufocanus (Sund.) and Microtus agrestis (L.). Ann. Zool. Fenn., 14: $53-93$.

30. Wiger R., 1981: Role of self-regulatory mechanism in cyclic population of Clethrionomys with special reference to C. glareolus; a hypothesis. Oikos, 38: $68-71$.

Accepted, September 6, 1985.

Maria MAZURKIEWICZ

WPEYW ROZMIESZCZENIA PODSZYTU NA UŻYTKOWANIE PRZESTRZENI PRZEZ POPULACJE NORNICY RUDEJ

\section{Streszczenie}

Badania były prowadzone w Puszczy Piskiej w latach $1976-1981$ na 1 ha powierzchniach w 9 różnych drzewostanach. Dane dotyczące liczebności i rozmieszczenia nornicy rudej zbierano metodą CMR przeprowadzając 4 razy do roku 7-dniowe serie połowów. Charakterystyka środowiskowa obejmowała ocenę wieku drzewostanu, typu siedliska oraz zagęszczenia i składu gatunkowego drzew i krzewów. Na podstawie różnicy w rozmieszczeniu przestrzennym podszytu wyróżniono 2 typy powierzchni: o losowym (R) i skupiskowym (C) jego rozmieszczeniu (Tabela 2). Stwierdzono, że przy podobnych liczebnościach populacji, nornica ruda użytkuje większą przestrzeń na powierzchniach o losowym rozmieszczeniu podszytu (R) niż na powierzchniach o jego rozmieszczeniu skupiskowym (C) (Ryc. 
1, 2). W okresie wzrostu liczebności populacji zajmowanie przez osobniki nowych punktów połowu następuje szybciej i zatrzymuje się na wyższym poziomie na powierzchniach typu $\mathrm{R}$ niż na powierzchniach typu $\mathrm{C}$ (Ryc. 3). Powoduje to osiąganie przez populacje wyższych zagęszczeń lokalnych na powierzchniach typu $\mathrm{R}$ w stosunku do powierzchni typu C przy podobnym zagęszczeniu ogólnym (Ryc. 4). Wielkość areałów osobniczych spada wraz ze wzrostem zagęszczenia lokalnego na obu typach powierzchni, ale utrzymuje się na różnym poziomie - wyższym na powierzchniach typu $\mathrm{R}$ (Ryc. 5, 6). Wielkości areałów osobniczych samic aktywnych płciowo sa podobne na obu typach powierzchni i wykazuja spadek wraz ze wzrostem ich zagęszczenia lokalnego (Ryc. 7). Srednia liczba osobników na punkt połowu wzrasta wraz ze wzrostem zagęszczenia lokalnego bardziej na powierzchniach typu $\mathrm{R}$ niż na powierzchniach typu $\mathrm{C}$, ale $\mathrm{w}$ relacji do wielkości areałów osobniczych na obu typach powierzchni osobniki utrzymują podobną liczbę kontaktów między sobą (Ryc. 6). Srednia liczba samic aktywnych płciowo na punkt połowu waha się około 1 niezależnie od ich zagęszczenia lokalnego. 